\title{
What is the 'World' in World Politics? : Heidegger, Badiou and Void Universalism
}

\section{Prozorov, Sergei}

2013-04-01

Prozorov , S 2013 , ' What is the 'World' in World Politics? Heidegger, Badiou and Void

Universalism ' , Contemporary Political Theory , vol. 12 , no. 2 , pp. 102-122 . https://doi.org/10.1057/cpt.2012.14

http://hdl.handle.net/10138/233453

https://doi.org/10.1057/cpt.2012.14

acceptedVersion

Downloaded from Helda, University of Helsinki institutional repository.

This is an electronic reprint of the original article.

This reprint may differ from the original in pagination and typographic detail.

Please cite the original version. 
This is a post-peer-review, pre-copyedit version of an article published in Contemporary Political Theory, vol. 12, issue 2. The final authenticated version is available online at: https://doi.org/10.1057/cpt.2012.14.

\title{
Dr. Sergei Prozorov
}

Docent in International Relations

Academy of Finland Research Fellow

Department of Political and Economic Studies

00014 University of Helsinki, Finland

Phone: +358-(0)9-19123822

Email: sergei.prozorov@ helsinki.fi

\section{What is the 'World' in World Politics? Heidegger, Badiou and Void Universalism}

\begin{abstract}
The article addresses the ontological presuppositions of the discourse on world politics in political and international relations theory. We argue that the ambivalent status of world politics is due to the understanding of its central concept, i.e. the world, in terms of totality or 'the whole'. Drawing on Alain Badiou's set-theoretical ontology, the article demonstrates that such a concept is logically inconsistent, which leads the discourse on world politics to a perpetual oscillation between the presupposition of a universal totality and the unmasking of its impossibility. We then proceed to the particularistic concept of the world as a limited totality with no pretense to universality, as developed in Heidegger's phenomenological ontology and Badiou's objective phenomenology. While this approach that affirms the existence of the infinity of infinite worlds appears of little use to the universalist problematic of world politics, it provides us with a pathway to the third concept of the world as the void, in which a plurality of positive worlds coexist and which is their ontological condition of possibility. We shall argue that only this concept of the world enables a logically consistent notion of universality as non-totalizable and immediate. The final section addresses the implications of this concept for rethinking world politics as a practice of transformation of particular worlds in accordance with the universal principles derived from the disclosure of the world as void.
\end{abstract}

Keywords: world politics, universalism, ontology, phenomenology, Martin Heidegger, Alain Badiou 


\section{WHAT IS THE 'WORLD’ IN WORLD POLITICS? HEIDEGGER, BADIOU AND VOID}

\section{UNIVERSALISM}

\section{The Ambivalence of World Politics}

The contemporary discourse on world politics in political and international relations theory oscillates between the two extremes of unproblematic presupposition and skeptical denial. On the one hand, the studies of global governance, norms, regimes and institutions take as a point of departure the existence of a worldwide dimension of politics, which is then specified in various ways. According to this logic, which is at work in e.g. idealist, liberal and constructivist theories, the referent domain of world politics exceeds the state-centric realm of 'international relations' and permits to incorporate into the discipline such formerly ignored problematics as gender, culture or identity as well as such formerly ignored actors as social movements, indigenous peoples and other minorities. In this manner, politics moves from the narrow confines of the international society of states to the widest possible, universal container of the world as a whole (see Lipschutz, 1992; Linklater, 1998; Wendt, 2003; Cerny, 2010). On the other hand, realist approaches as well as critical orientations from neoMarxism to post-structuralism, maintain their skepticism about the very possibility of attaining such a universal dimension of politics or remain wary of the hegemonic aspirations at work in any attempt to practice politics on a 'world' level (Pin-Fat, 2009; Calhoun, 2002; Rasch, 2003; Odysseos and Petito, 2007; Mouffe, 2009).

Despite their undeniable diversity, these approaches reproduce the ambivalent oscillation of the idea of world politics between a presupposition that is so self-evident as not to merit a conceptual explication and a problematic phantasm, only accessible to thought in the form of 
a hegemonic pretension (cf. Walker, 2009: 20-28). We either do not need to know what world politics means, since it is 'common knowledge', or we cannot know it, since such knowledge is inaccessible, inconsistent or plain false. This constitutive ambivalence may be illustrated with the help of two recent influential monographs on this subject, Jens Bartelson's Visions of World Community (2009) and RBJ Walker's After the Globe, Before the World (2009).

For Bartelson, the problematic status of the concept of the world community in the disciplinary discourse has to do with the differential logic of identity that has been constitutive of the discipline (Bartelson, 2009: 9-10). According to this logic, every identity is constituted by distinction from an 'other'. Since a world community would lack such an other by definition, it is henceforth impossible other than as a hegemonic imposture that claims for itself the universality it can never attain (cf. Abizadeh, 2005; Prozorov, 2011). In his historical analysis Bartelson demonstrates that this logic of identity is a relatively recent invention and can therefore be overcome by a return to an earlier understanding of world community as a wider cosmological context, in which a plurality of human communities are always already embedded. This emphasis on embeddedness directs Bartelson's attention to the cosmological visions, within which the ideas of world politics and world community have been articulated since the Middle Ages. These visions escape the differential logic of identity by 'positing a larger social whole within which all human communities are embedded and well as a vantage point over and above the plurality of individual communities from which this larger social whole can be understood' (ibid.: 20). Thus, it is possible to 'restore the default settings of political thought' (ibid.: 175) and reaffirm the world community no longer as an obscure telos of international politics, but as its very condition of possibility, something that is already here in the form of the presupposition, as long as human beings inhabit the same planet and share a common destiny. Yet, this reaffirmation 'depends on its coherence and persuasiveness on the existence of a cosmological vantage point situated over and above 
the plurality of human communities and the multitude of individual human beings.' (Ibid.:

In contrast to Bartelson's optimistic vision, R.B.J. Walker's After the Globe, Before the World exemplifies the tendency to render the universalist claims of world politics problematic. Walker addresses the ways in which numerous attempts to move from international relations to world politics remain caught up in what they try to transcend, i.e. the ontopolitical tradition of modernity, which is itself already an attempt at resolving the antinomies that we associate with world politics (e.g. universalism/particularism, nature/culture, individual/community, etc.) (Walker, 2009: 54-94). The 'seduction' and 'temptation' of world politics belong to the very tradition of the 'international' as its inherent transgression, something simultaneously desired and held impossible (ibid.: 24, 83).

Wherever we are, we are always 'before' the world, facing it as distant and inappropriable. Universalist claims are always '[enabled] within a particular array of boundaries, borders and limits' and a 'politics of the world' that promises to do away with those remains 'necessarily beyond reach'. (ibid.: 257-258) Thus, 'anyone seeking to reimagine the possibilities of political life under contemporary conditions would be wise to resist ambitions expressed as a move from a politics of the international to a politics of the world, and to pay far greater attention to what goes on at the boundaries, borders and limits of a politics orchestrated within the international.' (Ibid.: 2-3, see also 184-257) While there are numerous possibilities for political experimentation at these liminal sites, we would do well to remember that this experimentation always takes place on this side of the borderline.

Thus, while Bartelson seeks to 'deproblematize' the question of world community, trying to rid it of logical paradoxes by enfolding the problematic of community into an explicitly cosmological context and thus making the world the a priori site of any community 
whatsoever, Walker hypertrophies this question, making it practically impossible to exit the condition of the international at all.

It is easy to see that this perpetual debate cannot be restricted to the domain of 'IR theory proper', since it pertains to the ontological presuppositions that condition the very distinction between the domestic and the international, and hence between political and IR theory. ${ }^{1}$ Indeed, both Bartelson and Walker explicitly locate the question of world politics on the level of ontology, the universalist social ontology that precedes any possible 'nationalization' of community for Bartelson and the paradoxical yet resilient ontology grounding the international order for Walker. Since the argument of this article also remains on the ontological terrain, it is important to clearly define the concept of ontology that we shall rely on, all the more so because this concept is often deployed in diverse and somewhat confusing ways in political and IR theory. As Bruno Bosteels (2011: 241-242) has argued, the original Aristotelian sense of ontology as 'first philosophy', a science of being qua being frequently gives way to a rather more loose understanding of ontology in terms of 'the basic presuppositions behind a given politico-philosophical stance, the bedrock of fundamental assumptions and unshakable commitments', which might be better described as 'political anthropology' or even 'ideology'.

In order to avoid this reduction of ontology to a worldview, IR theorists have relied on the distinction between philosophical and scientific ontology (Patomaki and Wight, 2000: 215, Jackson, 2010: 29-31). While scientific ontology refers to a 'catalog of objects, processes and factors that a given line of scientific research expects to exist or has evidence for the existence of', philosophical ontology pertains to the question of our 'hook-up to the world, how we as researchers are able to produce knowledge in the first place' (Jackson, 2010: 28). While this distinction is helpful for highlighting the relation of substantive debates in IR 
theory to the fundamentals of philosophy of science (Jackson, 2010: 29-40), it is clear that neither 'philosophical' nor 'scientific' ontology actually captures the Aristotelian sense of the discourse on 'being qua being' that deals with all that exists but only insofar as it exists. Evidently, 'scientific ontology' as described by Jackson pertains to individual and particular beings or realms thereof (e.g. states, states' systems or statesmen) and not to being as such. In the terms of the two ontologists that we shall discuss in this article, Martin Heidegger and Alain Badiou, this approach would rather be termed ontical (Heidegger, 1962: 32-35) or phenomenological (Badiou, 2009a: 99-103). Yet, 'philosophical ontology' fares little better, insofar as in its investigation of our 'hook-up' to the world it supplants the question of being with the question of the knowledge of some beings by others, thereby slipping into the same ontical terrain, becoming indistinct from what we usually call 'methodology' (cf. Jackson, 2010: 32). This is not to denigrate either of the enterprises but only to point out that prior to the study of particular worldly beings in their positive predicates and the study of the conditions of our access to these beings there exists a level of inquiry that addresses these objects solely in the aspect of their being, bracketed off from their particular predicates. It is this level, which we may term formal ontology (Hennig 2008), that the argument of this article occupies.

While such an inquiry may appear excessively abstract, it does not imply a retreat into obscure and empty generality, since being, the object of ontology, is simultaneously the most universal and the most singular of all notions, accessible to us in the utmost facticity of our existence. 'Being is most universal, encountered in every being, and is therefore most common; it has lost every distinction, or never possessed any. At the same time, being is the most singular, whose uniqueness cannot be attained by any being whatever.' (Heidegger, 1991: 192) As we shall argue below, it is precisely this 'singular universality' of being that conditions the possibility of a consistent concept of world politics. 
In this article we shall draw on the insights from the phenomenological ontology of Martin Heidegger and the set-theoretical ontology of Alain Badiou in the discussion of three possible concepts of the world: the whole of beings (the world as 'everything'), a limited totality of beings (the world as 'something') and the void of being (the world as 'nothing'). We shall demonstrate that while the first concept is logically inconsistent and the second one inconsequential for the discourse on world politics, the third concept alone grounds a consistent form of universalism that rids the theory of world politics of its constitutive ambivalence. In the final section we shall address the possibility of a politics adequate to this universality. While the detailed analysis of this politics remains beyond the scope of this article, we merely seek to demonstrate the possibility of a universalist politics whose maxims are derived from our exposure to the world as void.

\section{The World as Everything}

Despite their diverging conclusions about the possibility of a world community, Bartelson and Walker converge in the basic assumption about the meaning of the 'world' in world politics. Bartelson's world, which is already 'behind' us as an all-encompassing whole, within which we are embedded, and Walker's world, which stands 'before' us as an unattainable universality, are one and the same world, understood in the sense of the Whole, a cosmos, universe or totality, in short, everything. This understanding of the world as the whole has arguably been at work in IR theory since its very emergence (see e.g. Morgenthau, 1948, chapters 29, 30; Carr, 1981; Schmitt, 1976; Burton, 1972; Boulding, 1985), and seems so perfectly in accordance with common sense and everyday language that it is difficult to see what could possibly be wrong with it. 
Let us posit the world as the whole, the sum of all beings. Such a totality must by definition count itself among its members, otherwise it would not be the sum of all beings, since it would remain outside itself. The world as the whole is thus endowed with a property of selfbelonging. It should therefore be possible to divide it into two parts: the parts of the world that belong to themselves, such as the world itself, and the parts that do not, such as e.g. a set of five apples which is not itself an apple. Let us then assemble the latter parts into a group of all parts that do not belong to themselves - a perfectly legitimate and even banal grouping, given that most multiplicities that we can think of are precisely not self-belonging. Yet, despite the banality of the predicate, this grouping turns out to be problematic as soon as we pose the question of whether it belongs to itself. If it does, it counts itself among its elements, which are defined by the property of not belonging to themselves. Yet, if it does not belong to itself, it must also count itself among its elements, which, after all, compose all the parts that do not belong to themselves. Whatever answer we choose, we end up with inconsistency, hence we must revise our original assumption and affirm that the world as the sum of all beings does not exist.

It is easy to recognize in this example the famous Russell's paradox which has been foundational for the formulation of axiomatic set theory in the early $20^{\text {th }}$ century. Yet, is settheoretical logic relevant to the grand debates on world politics? In fact, as long as we conceive of ontology in the Aristotelian sense as the study of being qua being, set theory offers the best paradigm of such a discourse. In Alain Badiou's famous argument, set theory is ontology pure and simple, since its object is not any particular class of beings defined by some positive predicates but rather everything that is insofar as it is: being as such is nothing but pure multiplicity that can be adequately grasped by set-theoretical axioms precisely insofar as they subtract being from the positive properties of beings (Badiou, 2005: 4-16). Sets are not a particular class of beings alongside others, e.g. human beings or social kinds, 
but rather the mode of presentation of all beings solely in their being (ibid.: 23-30). Evidently, the argument that set theory is ontology does not mean that being is 'composed of mathematical objectivities' but only asserts that set theory 'pronounces what is expressible of being qua being' and is therefore the most adequate form of ontological discourse (ibid.: 8).

From this perspective, the axioms of set theory necessarily pertain to everything that is, including the entities of the international domain and the world as the result of their totalization. To exclude these entities (be they states or persons, organizations or movements, etc.) from the field of application of set-theoretical axioms is simply to deprive them of being and reduce them to the status of simulacra, phenomenal apparitions without any ontological status. In short, as soon as we pose the problem of the world in ontological terms, the settheoretical argument on the inexistence of the whole appears not merely applicable to the discourse on world politics but of direct and paramount relevance to it.

We shall therefore conclude that concept of the world, understood in terms of cosmos, universe or totality, is inconsistent: the Whole has no being (Badiou, 2005: 40-42; 2009a: 109-111). We must emphasize that this claim does not merely concern the antiquated preGalilean conceptions of the closed totality of the cosmic order, whose crisis was addressed by Alexandre Koyre (1957) in his seminal work From the Closed World to the Infinite Universe. In fact, it is precisely because the world is infinite that it cannot be totalized into any figure of the whole, without violating Georg Cantor's theorem, foundational for set theory (see Badiou, 2005: 142-160, 265-280). For any set whatsoever, it is possible to construct a set, whose elements are all the subsets of the original set, a so-called 'power-set'. We may easily intuit that this set would be quantitatively greater than the original set: e.g. the number of possible combinations of any three letters $a, b$ and $c$ is eight $(a, b, c, a b, b c, a c, a b c$ and finally the void set $\varnothing$, which is included as a 'universal part' of any set and which we shall discuss in 
detail below). Cantor's theorem demonstrates that for infinite sets the size of the power-set is also greater than that of the original set, and, moreover, it is inaccessibly greater: it is possible to posit any infinite cardinal greater than that of the original set as the 'size' of its power-set (ibid.: 277-280).

The consequences of this theorem for any cosmological conception of the world are staggering. As soon as we posit the existence of the world as the whole, it is possible to construct a power-set of this world, which will be immeasurably greater than it, leaving an excess that cannot be incorporated into it. The same procedure can then be applied to this power-set and so on to infinity. There is thus no such thing as 'the absolutely infinite Infinity, the infinity of all intrinsically thinkable infinities' (ibid.: 277. Cf. ibid.: 283-284). The world as the whole is never all there is.

It is important to emphasize that the thesis on the inexistence of the Whole is an ontological claim about the world that should be rigorously distinguished from a rather more familiar and unobjectionable epistemological claim that our knowledge or representation of the world is never complete, while the world in itself might well be so, the claim that characterizes the post-Kantian position that Quentin Meillassoux termed 'correlationism' (Meillassoux, 2008: 5). Insofar as we take the axioms of set theory to pertain to the being of all there is, the epistemological failure or incapacity to know the world as a whole is converted into the ontological feature of the world as itself non-whole or non-totalizable (cf. ibid.: 51-53). Thus, contrary to the correlationist skepticism that perpetually refers this non-totalizability back to us as subjects of knowledge, Badiou's thesis on the inexistence of the whole affirms it as the feature of being itself, which, moreover, we may know perfectly well with no reason for any skepticism (Badiou, 2009a: 101-102). 


\section{The World as Something}

Having demonstrated that the world cannot be consistently posited as the whole, let us now consider the alternative possibility. The world may be posited as a limited totality with no pretense to universality, a something rather than everything.

Indeed, such a non-cosmological, 'local' concept of the world was dominant in the $20^{\text {th }}$ century phenomenology, particularly the early work of Martin Heidegger. In Being and Time Heidegger defined the world as a referential totality of Dasein's 'involvements' with other beings, the environment in which Dasein is absorbed in all kinds of references or assignments that involve various kinds of 'equipment', entities that are 'ready-to-hand' (zuhanden) for one's dealings in the world (Heidegger, 1962: 95-107). The detailed phenomenology of being-in-the-world in the First Division of Being and Time moves from the ontic understanding of the world as the totality of all the entities, i.e. the Whole we have dismissed as inconsistent, to 'that wherein a factical Dasein as such can be said to live.' (Ibid.: 93) This dwelling place is a practical context of Dasein's involvements with entities which are disclosed to it, not in an objectified manner of things present-at-hand (vorhanden) but in terms of practical functions that can be assigned to them and for which they available. The paradigm of Heidegger's phenomenology of the world is the workshop, a totality of tools assigned to certain practical functions, in which Dasein is involved (Harman, 2002: 15-48; Malpas, 2006: 182-189). Thus, the world is always already there for Dasein as the referential totality of its involvements and any discovery of a concrete entity in the world is only possible on the basis of our pre-understanding of the world, in which we dwell.

Alain Badiou's phenomenology, presented in his Logics of Worlds (2009a) offers a similar concept of the world as a limited totality. Nonetheless, in contrast to Heidegger, for whom the world is necessarily disclosed to Dasein, Badiou's phenomenology is 'objective', neutralizing 
any intentional or 'lived' dimension of the worlds he analyzes, making the existence of worlds entirely independent from human existence (Badiou, 2009a: 118-119). This accounts for a different relationship between ontology and phenomenology in Badiou's work. For Heidegger ontology was itself necessarily phenomenological in its method, since its condition of possibility was Dasein's pre-understanding of being, on whose basis the meaning of being is to be interpreted (Heidegger, 1962: 29-35, 49-63). In contrast, Badiou posits a rigorous disjunction between them while making both entirely independent of the existential analytic of Dasein (Badiou, 2009a: 118). While ontology deals with being in the set-theoretical sense of pure or inconsistent multiplicity, the phenomenology of Logics of Worlds focuses on the localization of being as 'being-there', appearance in a determinate and ordered situation. It is this situation, structured as a network of identities and differences, that Badiou terms the world. In more technical terms, the world is defined as a set that contains a transcendental and the transcendental indexing of all its elements (ibid.: 598).

The transcendental refers to the order-structure that assigns the entities in the world various degrees of intensity of appearance. Contrary to the more familiar concept of the transcendental in Kant's philosophy, Badiou's transcendental organization of the world is a strictly immanent process that accounts for the logical cohesion of appearance, which is not determined by the ontological composition of the situation - a key point we shall return to below (ibid.: 101, 121-122, 241-242). Transcendental indexing is a function that makes a degree of appearance (from the minimum to the maximum) correspond to a pair of elements of the set that appears in the world. On the basis of these operations Badiou builds up an elaborate phenomenology, in which any situation whatsoever, from a protest demonstration to a country house on an autumn evening, can be analyzed as a world, structured by a particular transcendental order. 
This conception of the world yields two important consequences. Firstly, on the basis of the principle of the inexistence of the whole, we may conclude that there is always more than one world (ibid.: 114-115). Moreover, since it is impossible to restrict the number of worlds in the absence of the whole, their number may therefore be posited as infinite. Secondly, every one of these worlds is itself infinite. It is impossible to delimit a world either from below through the dissemination of its elements or from above through their totalization (ibid.: 306-310, 331-335).

Thus, we have moved from the assumption of one world as the Whole to the infinity of worlds that are themselves infinite. Each of those worlds is characterized by a specific transcendental order that can be reconstituted through a Heideggerian or Badiouan phenomenology, but is at the same time part of a wider world and decomposable into smaller worlds that are also liable to phenomenological analysis. While this approach can be fruitfully applied in IR in the study of e.g. the 'worlds' of diplomatic negotiations, border policing or refugee camps, it is apparently of little help in rethinking world politics in its more familiar universalist sense, since world politics here is simply the politics that unfolds within a particular world in accordance with its transcendental order. The very question of political universality appears to be foreclosed by the plurality of worlds with particular orders above or between which no authority exists. Is not world politics then strictly synonymous to international relations and the world simply identical to the international domain that it was intended to transcend? (Walker 2009: 21-22) This is indeed the position of the diverse group of the critics of cosmopolitan universalism who affirm the pluralism of the international as the sole possible universal (see e.g. Jackson 2003, Connolly 1995, Mouffe 2009), whereby the world is nothing but a plurality of worlds and world politics consists in maintaining this plurality against any hegemonic totalization. 
Nonetheless, the universalization of the international as the 'world of all worlds' merely throws us back into logical inconsistency. Just as ontologically every set is a set of sets, so every world is in principle a world of worlds, i.e. it contains other worlds that appear in it (Badiou, 2005: 45; 2009: 112). It is therefore possible for the international world to contain an infinite multiplicity of worlds - the only thing that this or any other world cannot contain is everything. Thus, as Walker demonstrates admirably, one will never reach world politics if one begins from the international (Walker, 2009: 26-31). Yet, while this claim leads Walker to a profound skepticism about world politics as such, the impossibility of passing from the international to the world is only a problem as long as we continue to envision the universality of world politics as necessarily mediated by particularity (cf. Pin-Fat 2009). If the world of the international is a particular world among others and, as Walker argues at length, its particular transcendental is historically contingent, the impossibility of arriving at the universality of world politics from the particularism of the international simply entails the need for another starting point for conceptualizing the universality of world politics. Since presupposing the world as the whole leads us to inconsistency and starting from particular worlds leads us nowhere, this new starting point is obtained by abandoning every totalizing conception of the world and asserting its universality without recourse to any mediation by the particular. It is this solution that we address in the following section.

\section{The World as Nothing}

While at first glance the particularistic conception of worlds merely confirms the impasse of the discourse of world politics due to the inaccessibility of the universal, it actually guides us towards a solution to our problem by raising the question of the conditions of appearance of this infinity of worlds. Simply put, where are all these worlds? Just as we commonly speak of 
all the species, books or mountains in the world, we may speak of the infinity of worlds existing 'in the world'. But what is this world in which the infinity of positive, transcendentally regulated worlds comes to appearance? If this 'world of all worlds' were itself a positive world, it would have to be a self-belonging universal set, which we have dismissed as logically inconsistent. This world must therefore be a non-positive site, in which an infinity of positive worlds comes to appearance. Yet, what could this 'in which' possibly be?

From ancient Greek atomism onwards, this problem has been resolved by asserting that whatever exists positively does so in the empty space, vacuum or void, in short - Nothing (see Gregory, 1981; Badiou, 2009b: 56-64). Indeed, this answer appears to be the last remaining logical possibility: if we have excluded the possibility of the world being everything and we are not satisfied with a particularistic understanding of the world as something, then it can only be nothing. Yet, everything depends on how we understand this 'nothing'. As long as it is understood in the merely negative sense of privation, lack or absence, we remain within the political ontology of the international for which there are only particular worlds and nothing beyond them. However, it is also possible to understand the claim about the nothingness of the world as a pure affirmation: there is a world, in which an infinity of infinite worlds appears, and this World, which we shall henceforth capitalize to distinguish it from worlds as limited totalities, is nothing but the void.

Let us elucidate this concept of the World by revisiting Heidegger's work after Being and Time, in which there is a gradual shift away from the understanding of the world as a practical context of Dasein's activity towards an ontological concept of the world (cf. Malpas, 2006: 186-189). In his 1929-1930 course of lectures The Fundamental Concepts on Metaphysics Heidegger argues that '[ordinary] understanding cannot see the world for beings. 
In relation to the individual trees and the way they are gathered together the forest is something else. It is that out of which the many trees belong to a forest.' (Heidegger, 1995: 347) The World is thus neither $a$ being nor an aggregation of all beings in a particular world but rather the opening, in which particular worlds become disclosed for the first time. This opening is not immediately manifest to the inhabitant of a particular world but can only disclose itself through the awakening of a 'fundamental attunement' or mood (Stimmung). In the Fundamental Concepts of Metaphysics this world-disclosing mood is described as profound boredom, which Heidegger analyzes in terms of two 'structural moments': being left empty and being held in limbo (ibid.: 82-88, 113-125, 136-143).

The first moment refers to a state of indifference that envelops all the beings including Dasein itself. No possibility of action or use is available to Dasein which finds itself suspended in the midst of beings that 'refuse themselves' and have 'nothing to offer' to it. The second moment, being held in limbo, is closely related to this suspension. The beings that refuse themselves are nothing other than possibilities of Dasein's existence that are left unexploited. However, this withdrawal of concrete possibilities 'impels' Dasein towards a more originary 'making possible', the sheer potentiality of existence from which specific possibilities arise (ibid.: 143-144). In the mood of profound boredom Dasein is simultaneously entranced by the emptiness of the total indifference of beings and impelled towards what Heidegger calls the 'moment of vision' (ibid.: 151-152, cf. Heidegger 1962, 384-400), a resolute grasp of authentic existence, in which world disclosure takes place.

Yet, what exactly is disclosed here? It is purely and simply nothing, the emptiness arising from beings refusing access to themselves and the void of Dasein's existential possibilities. 'The openness at stake is essentially the openness to a closedness, and whoever looks in the open sees only a closing, only a not-seeing.' (Agamben 2004: 68. See also Heidegger, 1973: 
169-180) The opening of the World is nothing more than the result of the subtraction of the human being from its particular world.

The metaphysical problem of the nothing is elaborated in Heidegger's 1929 lecture 'What is Metaphysics?' In this lecture, Dasein is explicitly defined as 'being held out into the nothing' (Heidegger, 1973: 108) and this nothing is posited as the paradoxical 'ground', in which all beings come to appear: Ex nihilo omne ens qua ens fit [from the nothing all beings as beings come to be] (ibid.). While traditionally metaphysics tended to approach nothing as the 'counter-concept of being', its pure and simple opposite, Heidegger demonstrates the way, in which nothing, which is indeed not $a$ being, nonetheless discloses the being of beings as such, i.e. the difference of all beings with respect to the nothing: '[The Nothing] discloses these beings in their full but heretofore concealed strangeness as what is radically other with respect to the nothing. Only on the ground of the original revelation of the nothing can human existence approach and penetrate beings.' (Ibid: 103. Cf. Harman, 2002: 90-95) Thus, while in a fundamental attunement such as boredom Dasein can rise above the 'superficies of existence' (ibid.: 104) and approach beings in their being, this 'rise above' does not take one to another place of the abundance of beings and the plenitude of possibilities, but rather entails the slipping away of these beings and possibilities, so that Dasein stands alone in the void of the World as the 'lieutenant of the Nothing' (ibid.: 106).

The theme of the world as the void culminates in Heidegger's 1947 Letter on Humanism, in which he reinterprets the human as a 'worldly' being. Against the contrast between 'worldly' and 'spiritual' in everyday language, Heidegger understands Dasein's wordliness in terms of its transcendence of any particular being or realm of being (i.e. a positive world) through being "placed freely into the clearing of Being, which alone is "world": 
[For] us 'world' does not at all signify beings or any realm of beings but the openness of Being. Man stands out into the openness of Being. 'World' is the clearing of Being into which man stands out on the basis of his thrown essence. World is in a certain sense precisely 'the beyond' within existence and for it. (ibid.: 252)

Thus, Heidegger's conception of the world moves from the phenomenology of the particular world as an immanent practical context of Dasein's activity to the affirmation of the World as the void or clearing, in which such worlds are disclosed in the first place. The void is therefore the condition of possibility of any positive world whatsoever: it is that in which these worlds appear, but, in contrast to the two concepts of the world addressed above, it neither totalizes these worlds into the whole nor is mediated by them. Nonetheless, this approach poses the question of the relation between the World as void and the positive worlds, be these the worlds of diplomacy, development, migration or war. If these worlds simply come to appearance against the background of the void as 'not nothing', the World appears to be little more than a logical condition that can hardly ground any politics, reduced as it is to a neutral support of the infinite proliferation of positive worlds coexisting in the vacuum. In this manner, politics is 'deontologized' and reduced to the positive principles governing autonomous worlds, between which no adjudication is possible. Instead of universalism, we end up with nihilism and relativism, which in the context of the discussion of Heidegger take an even more ominous and historically concrete form of Nazism.

While any serious consideration of the 'Heidegger problem' goes beyond the scope of this article, our reconstruction of the concept of Heidegger's concept of the World as void at least permits us to offer a new perspective on it. Nihilism, to which Nazism was a historical response and of which it was the historical nadir, is not constituted by embracing the 
ontology of the World as void, but rather by its negation. Nihilism is a disposition that wants to 'know nothing of the nothing', reducing it to a mere 'nullity' (Heidegger, 1977: 96). In Introduction to Metaphysics Heidegger defined nihilism in terms of 'chasing after beings' in the 'oblivion of being itself', which we may rephrase in terms of the valorization of worlds in the oblivion of the World:

But where is the real nihilism at work? Where one clings to current beings and believes it is enough to take beings, as before, just as the beings that they are. But with this, one rejects the question of being and treats being as a nothing (nihil), which in a certain way it even "is," insofar as it essentially unfolds. Merely to chase after beings in the midst of the oblivion of being - that is nihilism. (Heidegger, 1961: 217)

If the void of the World is reduced to the neutral nothingness as the background for the appearance of positive worlds, no universality is conceivable, since the infinite plurality of positive orders is all there is. The formula of nihilism may thus be summed up as follows: 'there are only positive worlds and nothing besides them'. Yet, if this is the case, then there is no political principle that could transcend the positive order of the world and in terms of which this order could ever be found illegitimate: everything is permissible if a particular transcendental order permits it. In this manner, Nazism becomes possible as a world, in which the negativity of annihilation paradoxically reigns as the supreme ordering principle.

Yet, it is important to bear in mind that it only becomes possible as a result of the negation of the World as void, its nullification as politically inconsequential and incapable of grounding any universalist politics. While Heidegger admittedly could not resist the temptation of this nullification himself, his thought at least permits us to trace this ontopolitical gesture in Western metaphysics, which is the first step in the direction of its overcoming. The second 
step in this direction consists in elucidating the relation between the ontology of the World and the phenomenology of worlds, which will make the concept of the World as void politically consequential and thereby redeem its universalist potential. In the following section we shall pursue this question in an analysis of Alain Badiou's ontology.

\section{The World and Worlds}

While Badiou restricts the term 'world' to the positive totalities regulated by a transcendental order, the void is the most important concept in his ontology and functions in the manner resonant with Heidegger's clearing yet also radicalizing his ontological insight. Ironically, while in 'What is Metaphysics?' Heidegger famously accused mathematics and other exact sciences of being incapable of treating the nothing (ibid.: 94-95), Badiou's use of the settheoretical category of the void set to ground ontology demonstrates precisely the kind of engagement with the nothing that Heidegger sought. More generally, although it could plausibly be argued that Heidegger and Badiou agree on almost nothing with regard to either philosophy or politics, what they actually $d o$ agree about is the Nothing itself, the ontological status of the void as the condition of possibility of positive worlds.

In Logics of Worlds, Badiou departs from the void as the first determinable set. Since in a settheoretical ontology one can only posit a set if one can determine its composition, it is possible to immediately determine a set that has no elements, i.e. the void set $\varnothing$. The thinkability of all other sets depends on their belonging to specific worlds. Yet, since the void set has no elements, it logically appears in any world whatsoever:

[Since] the void is the only immediate being, it follows that it figures in any world whatsoever. Without the void, there is no world, if by 'world' we 
understand the closed place of an operation. Conversely, where something operates - that is, where there is world - the void can be attested. (Badiou, 2009a: 114. Emphasis added.)

While for Heidegger every particular world must be disclosed in the void, for Badiou it is the void itself that appears in every positive world. Moreover, in contrast to Heidegger, for Badiou the void is not merely the clearing of being but literally its building block, so that whatever appears in the world ultimately depends on the void for its being. To recall, what appears in Heidegger's clearing, i.e. beings and worlds as 'realms of beings', is not itself composed of the clearing but is disclosed against the background of the Nothing as precisely not nothing. For Badiou beings are instead 'woven out of the void' (Badiou, 2005: 57. Cf. Badiou 2009a: 112-113). This does not mean that everything is in fact made of nothing, but merely that in order to be grasped in the aspect of their being, beings must be subtracted from all positive predicates they are endowed with in the particular worlds, just like Dase in is in the mood of profound boredom (Badiou, 2005: 58). For this reason, ontology is equivalent to a theory of the void and, moreover, can only be a theory of the void, since if it asserted the existence of other beings, it would reduce itself to phenomenology, i.e. the description of the transcendental orders of particular worlds. Ontology must therefore begin and end with the void, all of its terms being derived from the void alone (Badiou 2005, 57).

[The] absolutely primary theme of ontology is therefore the void - the Greek atomists, Democritus and his successors, clearly understood this - but it is also its final theme because in the last resort, all inconsistency is unpresentable, thus void. If there are 'atoms', they are not, as the materialists of antiquity believed, a second principle of being, the one after the void, but compositions of the void 
itself, ruled by the ideal laws of the multiple whose axiom system is laid out by ontology. Ontology, therefore, can only count the void as existent. (Ibid.: 58)

All the beings of every world are, in their being, compositions of the void. With the help of the axioms of set theory, it is possible to generate an infinite number of sets from the void alone. Thus, the World as void is not merely the 'nothing' against whose background beings emerge but rather the ontological condition of possibility of all the beings, which appear in all positive worlds. Insofar as the void figures in any world whatsoever, it is a 'universal part' (ibid.: 86-88), underlying the constitution and structuration of every particular world. It is easy to see that the universality of this 'part' satisfies our criteria of immediacy and nontotalizability: insofar as the World is nothing, it is the very opposite of the Whole, and insofar as it is the ground of all being, it is always already there, immediately, in any world whatsoever. Thus, the World is the universal that precedes and exceeds the constitution of anything particular, making possible the proliferation of the infinite number of worlds while proscribing their aggregation into the whole.

While the World is in every world, it is important to emphasize that there is no necessary relation between the World as void and the positivity of worlds. If one could infer appearance from being, there would only be one positive world whose transcendental order would somehow 'correspond' to the void - that world would have to be the whole and is therefore impossible. It is nonetheless possible to make the opposite move of inferring being from appearance that would establish 'an ontological halting point' (Badiou, 2009a: 195) to the infinite proliferation of intra-worldly appearances. In Badiou's postulate of materialism, 'every atom of appearance is real' (ibid.: 218-220), so that whatever appears in the world must have an ontological correlate, a multiplicity composed of the void. 
Thus, we end up with the tripartite scheme, in which the abyss between an infinity of positive worlds and the void of the World is bridged by the ontology of pure multiplicity: the void of being - beings composed of the void - beings ordered in worlds. What the World makes possible is not this or that world in particular but rather the proliferation of being as inconsistent multiplicity, which is then ordered in accordance with the transcendental of a given world. In other words, the World as void brings forth the ontological material for the construction of worlds that ensures that whatever appears is real without prescribing how it should appear. Thus, while whatever appears in the world is necessarily grounded in real being, the mode of its appearance, prescribed by the transcendental order of the world, is absolutely contingent, having no ontological correlate.

\section{Is There a Politics of the World?}

The elucidation of the relation between the World and worlds makes it possible to revisit the question of world politics. We have demonstrated that this politics cannot take the form of the totalization of all the beings into the world state or other figure of the whole. Nor does this politics consist in the infinite ascent towards universality through the mediation of particular worlds or their perpetual expansion. Yet, what kind of politics could possibly follow from the understanding of the World as the void, in and from which an infinite number of worlds emerges?

The first conclusion to be drawn from the concept of the World as void consists in the affirmation of the contingency of every world, insofar the transcendental order that conditions its appearance has no foundation in being. The disclosure of the World within positive worlds demonstrates that every world is literally founded on nothing, disturbing its 
transcendental order and opening it up to the possibility of transformation. Understood in this sense, a politics of the World consists in coming to terms with the radical contingency of the infinity of worlds that we inhabit, which enables the contestation and transformation of their orders. $^{2}$

Yet, is this all there is to the politics of the World? Does it have any content beyond the affirmation of the contingency of every positive world that leaves political prescription up to these worlds themselves, ending up with a radical pluralism that grants no ontological privilege to any particular world and is thus incapable of adjudicating between the politics within different worlds? It is clear that the politics of the World cannot affirm any principle or value that would derive from the positive order of a world, be it tradition or law, identity or culture. No particular being or realm of beings could be the source of such principles, whose only ground must be being itself. Yet, being itself is precisely the void, in which worlds appear for Heidegger and from which they are woven for Badiou. What political prescription could possibly follow from Nothing?

Two answers to this question immediately spring to mind. Firstly, insofar as the World is void, it prescribes nothing, i.e. there is no such thing as a politics of the World beyond the coexistence of intra-worldly political orders. Secondly, insofar as the world is void, it may prescribe anything, by analogy with the principle of ex falso quodlibet: anything at all follows from nothing. Whatever politics is practiced in a particular world, it is 'founded' by the void to an equal degree to any other politics. Either way, no positive political principle may be inferred from the World, which is merely an indifferent vacuum, in which an infinite number of contingent worlds coexist. If all the ontology of the World as void could politically prescribe were either nothing or anything, we would be stuck in nihilism, either a 'passive nihilism' of a weary particularism resigned to the ways of one's world or an 'active nihilism' 
of a rampant particularism that arbitrarily posits its own prescriptions (cf. Nietzsche, 1968: $16-18)$.

Nonetheless, there is a third possibility of a genuinely universal political prescription that follows precisely from the affirmation of contingency. For the contingency of a positive world to become manifest, the World as void must first come to appearance within this world, i.e. be disclosed to a worldly being. As we have argued, this disclosure of the World takes place in an attunement that Heidegger refers to as 'standing out in the nothing'. This condition is attained when we subtract ourselves from the positive transcendental order of our world, ending up 'left empty' and 'held in limbo' due to the suspension of both our own intra-worldly identities and our relations with other beings of the world. As a result of this subtraction, the transcendental of the world, which is nothing but the relational network that regulates the appearance of beings, is rendered inoperative and, as it were, comes undone.

Yet, this suspension of the transcendental does not entail the disappearance or dissolution of the beings of the world, but only that they now appear solely in their being, as a pure inconsistent multiplicity devoid of positive identity or relational order (Badiou, 2005: 25). We shall term this zero degree of appearance 'being-in-the-World', in contrast to Heidegger's positive and relational 'being-in-the-world'. Giorgio Agamben (1993: 1-3, 96) has famously termed this mode of appearance 'whatever being' or 'being-thus': being that is solely its manner of being, subtracted from all identitarian predicates and wholly exposed in its facticity. In other words, in their subtraction from the transcendental of the world 'whatever beings' undergo neither a deprivation (of the old identity) nor a transformation (into a new one), but solely the exposure of the fact that they are in the absence of any identification of what they are. 
Thus, the disclosure of the World within positive worlds also transforms the beings to whom it is disclosed, reducing their positive and transcendentally regulated being-in-the-world to the subtractive mode of being-in-the-World, in which all that appears is being itself. Evidently, if there were to exist a politics of the World that would go beyond the affirmation of the pluralism of worlds but whose maxims would be irreducible to positive intra-worldly principles, this austere condition could be its sole possible foundation. While the World as void cannot be the source of political maxims, they may nonetheless be derived from beingin-the-World as the attunement that we as worldly beings must enter for the World to be disclosed in the first place.

While this derivation is beyond the scope of this article, let us merely illuminate its logic by considering such familiar political principles as freedom, equality and community. These maxims have historically served as positive intra-worldly principles governing particular, e.g. liberal, socialist or nationalist worlds. Moreover, all three of them have been deployed tendentiously and hypocritically in hegemonic and often violent attempts to universalize these particular worlds. There is certainly no shortage of critical studies exposing the way the alleged universality of these principles was used to legitimize particularistic, inegalitarian and exclusionary forms of politics. And yet, the concepts of freedom, equality and community have also been reinterpreted in contemporary continental thought on the basis of the affirmation of pure being devoid of any positive identitarian predicates (see respectively Nancy 1994, Ranciere 1999, Agamben 1993).

Grasped as the attributes of being-in-the-World, freedom, equality and community are no longer reducible to ideologies, values or norms of a particular origin, Western or otherwise, but rather describe the condition attained by the withdrawal from any intra-worldly norm. The mode of their functioning is thus strictly axiomatic, devoid of any intra-worldly 
foundation and referring to that which remains when worldly beings are subtracted from all such foundations and are exposed in the pure facticity of their being. From this perspective, these axioms are simultaneously transcendent and immanent in relation to the worlds in which they are affirmed. Insofar as they are derived from the subtraction from every intraworldly determination, they are by definition transcendent in relation to all worlds. Yet, since the void of the World is the universal part of every world, these axioms are also immanent to every world in which they are advanced. In Jean-Luc Nancy's formulation, they are transimmanent, transcending the positivity of the world not from above or beyond but from within (Nancy, 1998: 55).

It is thus possible to conceive of the politics of the World that goes beyond the mere affirmation of the contingency of all worlds towards the transformation of these worlds on the basis of the axioms arising from being-in-the-World as the condition, in which the void of the World is disclosed. This transformation consists in the production within worlds of the positive effects of these axioms, i.e. the overcoming and neutralization of intra-worldly hierarchies, exclusions and restrictions that have no ontological correlate in the name of freedom, equality and community of all beings as whatever beings. ${ }^{3}$ Thus, the axioms of being-in-the-World give concrete content to a universalist world politics that is no longer suspended between passive and active nihilism, between 'nothing works' and 'anything goes' but rather strives to enhance freedom, equality and community in an infinity of infinite worlds where it is practiced.

While these axioms are valid for all worlds, the task of world politics does not consist in the aggregation of the infinity of worlds into an 'over-world' constituted on their basis. However 'global' in its scope, such an overworld could never contain all worlds and would thus remain a particular world among others, devoid of any ontological privilege over more 'local' 
worlds. Yet, neither can such a privilege be granted to the plurality of local worlds, since the contingency of worlds does not depend on their size or any other immanent characteristic. Thus, integration and fragmentation are equally legitimate pathways for world politics, which has no privileged site, level or method but is defined solely by its content, the universal axioms derived from being-in-the-World. World politics does not derive its name from the fact that it unites all worlds into the whole but from the fact that it affirms the same axioms arising from the disclosure of the void of the World in whatever world it is practiced. 
NOTES

${ }^{1}$ See Abizadeh 2005, Albert, Cederman and Wendt 2010, Wendt 2003, Cerny 2010, Pin-Fat 2009, Beardsworth 2011 for diverse attempts to reconceptualise universality in world politics. See also Prozorov 2009, 2011 for a critical discussion of the prevalent understanding of the universal in IR theory as split between the particularistic pluralism of the international and the hegemonic totality of the world state, and the outline of the alternative approach that I term 'generic universalism'.

2 This affirmation of contingency of worlds is given a more radical interpretation in the work of Quentin Meillassoux, whose ontology dispenses with Leibnitz's principle of sufficient reason and asserts the absolute contingency of all that is as the sole necessity (Meillassoux, 2008: 65-81). Drawing on Cantor's theorem discussed above, Meillassoux proceeds to make this radical contingency or 'hyper-chaos' compatible with the empirical stability of worlds: insofar as there is no Whole, the application of probabilistic reasoning, which presupposes the totality of all possible outcomes, is no longer legitimate. It is thus possible to conceive of a world that exists for no reason whatsoever yet remains remarkably stable. With regard to politics, this approach tempers the optimism usually associated with the affirmation of contingency: the fact that the order of a given world is not necessary only means that its transformation is always possible and tells us nothing about its likelihood. Meillassoux's own ethico-political stance, in which the eschatological awaiting of the (as yet) inexistent God is combined with a 'finite' politics aware of its limits (Meillassoux, 2011: 162-163), testifies to the political ambivalence of the idea of contingency.

3 This approach resonates with Badiou's understanding of politics as a 'generic' truth procedure that produces within worlds the positive consequences of the eruption of the event, which is defined in set-theoretical terms as a self-belonging set, whose belonging to the world is undecidable and which exposes the world's ontological inconsistency, convoking the void within it. The intervention that declares the occurrence of the event and the continuous fidelity to it in the form of the production of its effects ('truths') constitute the subject of politics as a finite fragment of its procedure. Thus, in our terms the political subject is a worldly being that produces positive effects of the event of the World within its world, transforming it in accordance with the axioms of being-in-the-World. See Badiou 2005: 335353, 391-405; 2008a: 147-175. For a more detailed reading of Badiou in the context of world politics see Prozorov 2009. The key difference of our approach to world politics is that while for Badiou the content of the political 'truth' is limited to the axiom of equality, we also include into this list freedom and community, which Badiou all too quickly downgrades to the status of intra-worldly ordering principles (Badiou, 2008a: 171-173). Thus, in contrast to Badiou's affirmation of egalitarianism as the only 'true politics', we suggest that there is in fact a plurality of modes of politics, defined by what axiom of being-in-the-World (or a combination thereof) they affirm. 


\section{Bibliography}

Abizadeh, A (2005) 'Does Collective Identity Presuppose an Other? On the Alleged Incoherence of Global Solidarity', American Political Science Review 99 (1): 45-60.

Agamben, G (1993) The Coming Community. Minneapolis: The University of Minnesota Press.

Agamben, G (2004) The Open: Man and Animal. Stanford: Stanford University Press.

Albert, M, Cederman, L-E, and Wendt, A (2010), New Systems Theories of World Politics. Basingstoke: Palgrave.

Badiou, A (2003) Theoretical Writings. London: Continuum.

Badiou, A (2005) Being and Event. London: Continuum.

Badiou, A (2008a), Conditions. London: Continuum.

Badiou, A (2008b) The Meaning of Sarkozy. London: Verso.

Badiou, A (2009a) Logics of World. London: Continuum.

Badiou, A (2009b) Theory of the Subject. London: Continuum.

Badiou, A (2011) Second Manifesto for Philosophy. London: Polity.

Bartelson, J (2009) Visions of World Community. Cambridge: Cambridge University Press.

Beardsworth, R (2011), Cosmopolitanism in International Relations Theory. London: Polity Press. 
Boulding, K (1985) The World as a Total System. London: Sage.

Burton, J (1972) World Society. Cambridge: Cambridge University Press.

Calhoun, C (2002) 'The Class Consciousness of Frequent Travelers: A Critique of ReallyExisting Cosmopolitanism', South Atlantic Quarterly 101(4): 869-897.

Carr E.H. (1981) The Twenty Years' Crisis 1919-1939. Basingstoke: Palgrave.

Cerny, P. (2010), Rethinking World Politics: A Theory of Transnational Pluralism. Oxford University Press.

Connolly, W (1995) The Ethos of Pluralization. Minneapolis: The University of Minnesota Press.

Gregory, J. C. (1981) A Short History of Atomism. London: A. and C. Black.

Harman, G (2002) Tool-Being: Heidegger and the Metaphysics of Objects. Chicago: Open Court.

Heidegger, M (1962) Being and Time. New York: Harper Collins.

Heidegger, M (1977) Basic Writings. New York: Harper Collins.

Heidegger, M (1991) Nietzsche, vols 3 and 4. New York: Harper Collins

Heidegger, M (1995) The Fundamental Concepts of Metaphysics: World, Finitude, Solitude. Bloomington: Indiana University Press.

Hennig, B (2008) 'What is Formal Ontology' in Munn, K. and Smith, B., eds., Applied Ontology. An Introduction. Frankfurt: Ontos Verlag. 
Jackson, R (2003) The Global Covenant: Human Conduct in the World of States. Oxford: Oxford University Press.

Jackson, P.T. (2010) The Conduct of Inquiry in International Relations: Philosophy and Science and its Implications for the Study of World Politics. London: Routledge.

Koyre, A (1957) From the Closed World to the Infinite Universe. Baltimore: The John Hopkins University Press.

Linklater, A (1998) The Transformation of Political Community. London: Polity.

Lipschutz, R (1992) 'Reconstructing World Politics: The Emergence of Global Civil Society', Millennium 21 (3): 389-420.

Malpas, J (2006) Heidegger's Topology: Being, Place, World. Cambridge: The MIT Press.

Meillassoux, Q (2008) After Finitude: An Essay on the Necessity of Contingency. London: Continuum.

Meillassoux, Q (2011) 'Interview with Quentin Meillassoux' in Harman, G, Quentin Meillassoux: Philosophy in the Making. Edinburgh: Edinburgh University Press.

Morgenthau, H (1948) Politics Among Nations: The Struggle for Power and Peace. New York: McGraw Hill.

Mouffe, C (2009) 'Democracy in a Multipolar World', Millennium 37 (3): 549-561.

Nancy, J-L (1994) The Experience of Freedom. Stanford: Stanford University Press.

Nancy, J-L. (1998) The Sense of the World. Minneapolis: The University of Minnesota Press.

Nietzsche, F (1968) The Will to Power. New York: Vintage. 
Odysseos, L and Petito, F (eds) (2007) The International Political Thought of Carl Schmitt. London: Routledge.

Patomaki, H and Wight, C (2000) 'After Post-Positivism: The Promises of Critical Realism', International Studies Quarterly 44 (2): 213-237.

Pin-Fat, V (2009) Universality, Ethics and International Relations: A Grammatical Reading. London: Routledge.

Prozorov, S (2009) 'Generic Universalism in World Politics: Beyond International Anarchy and the World State', International Theory 1 (2): 215-247.

Prozorov, S (2011) 'The Other as Past and Present: Beyond the Logic of Temporal Othering in IR Theory', Review of International Studies 37 (3): 1273-1293.

Ranciere, J (1999) Disagreement: Politics and Philosophy. Minneapolis: The University of Minnesota Press.

Rasch, W (2003) 'Human Rights as Geopolitics: Carl Schmitt and the Legal Form of American Supremacy', Cultural Critique 54: 127-143.

Schmitt, C (1976) The Concept of the Political. Chicago: The University of Chicago Press.

Walker, RBJ (2009) After the Globe, Before the World. London: Routledge.

Wendt, A (2003) 'Why a World State is Inevitable', European Journal of International Relations 9 (4): 491-542. 